\title{
HUBUNGAN KUALITAS PELAYANAN DENGAN KEPATUHAN \\ PEMERIKSAAN KEHAMILAN (K4) PADA IBU HAMIL TM III DI BPM DYAH SURTI GONILAN SUKOHARJO 2017
}

\author{
Ajeng Novita Sari ${ }^{1)}$, Sab'ngatun' ${ }^{2}$ \\ ajengnovitasari@yahoo.co.id, sabngatun@yahoo.com \\ D III Kebidanan STIKES Mamba'ul 'Ulum Surakarta \\ Jl. Ring Road Utara KM.03 Mojosongo Jebres Surakarta \\ Telp/Fax (0271) 727182
}

\begin{abstract}
Abstrak
Masalah Kesehatan Ibu dan Anak (KIA) merupakan masalah nasional yang perlu mendapat prioritas utama karena sangat menentukan kualitas Sumber Daya Manusia (SDM) pada generasi mendatang. Tingginya Angka Kematian Ibu (AKI) menunjukkan bahwa pelayanan ANC sangat mendesak untuk ditingkatkan baik dari segi jangkauan maupun kualitas pelayanannya.Tujuan penelitian ini adalah untuk mengetahui hubungan kualitas pelayanan dengan kepatuhan pemeriksaan kehamilan (K4) pada ibu hamil Trimester III di BPM Dyah Surti Gonilan Sukoharjo tahun 2017.

Jenis penelitian ini menggunakan deskriptif kuantitatif dengan rancangan cross sectional. Populasi dalam penelitian ini adalah Ibu hamil Trimester III yang melakukan pemeriksaan kehamilan di BPM Dyah Surti Gonilan Sukoharjo dengan sampel sebanyak 37 responden dengan teknik accidental sampling.Teknik pengumpulan data menggunakan kuesioner dan checklist. Teknik analisis data menggunakan chi square.

Hasil penelitian menunjukkan bahwa mayoritas umur responden adalah 20-35 tahun sebanyak 22 orang $(59,6 \%)$ dengan tingkat pendidikan tinggi sebanyak 27 responen $(73,0 \%)$ dan mayoritas responden bekerja yaitu sebanyak 24 orang $(64,9 \%)$. Mayoritas responden yaitu sebanyak 22 orang (59,5\%) menyatakan bahwa kualtias pelayanan ANC dalam kategori baik. Mayoritas responden yaitu sebanyak 23 responden $(62,2 \%)$ menyatakan patuh dalam pemeriksaan kehamilan. Ada hubungan yang bermakna antara kualitas pelayanan ANC dengan kepatuhan pemeriksaan kehamilan Ibu hamil Trimester III yang melakukan pemeriksaan kehamilan di BPM Dyah Surti Gonilan Sukoharjo dengan nilai $\mathrm{X}^{2}=5,268$ dan $p$ value $0,022<0,05$.
\end{abstract}

Kata kunci : kualitas pelayanan, pemeriksaan kehamilan, ibu hamil

\section{Pendahuluan}

Kesehatan merupakan hak asasi manusia dan salah satu unsur kesejahteraan yang harus diwujudkan sesuai dengan cita-cita bangsa Indonesia sebagaimana dimaksud dalam Pancasila dan Undang-Undang Dasar Negara Republik Indonesia Tahun $1945 .{ }^{1}$

Masalah Kesehatan Ibu dan Anak (KIA) merupakan masalah nasional yang perlu mendapat prioritas utama karena sangat menentukan kualitas Sumber Daya Manusia (SDM) pada generasi mendatang. Tingginya Angka Kematian Ibu (AKI) menunjukkan bahwa pelayanan untuk meningkatkan kesehatan ibu dan anak sangat mendesak untuk ditingkatkan baik dari segi jangkauan maupun kualitas pelayanannya. 2

Berdasarkan kesepakatan Global (Milenium Development Goals/ MDGs, 2000) pada tahun 2015 diharapkan Angka Kematian Ibu (AKI) menurun sebesar tiga perempatnya dalam kurun waktu 19902015. Menurut data Survei Demografi Kesehatan Indonesia (SDKI) pada tahun 2002 angka kematian ibu sebesar 307 per 100.000 kelahiran hidup, pada tahun
2007 Angka Kematian Ibu sebesar 228 per 100.000 kelahiran hidup dan pada tahun 2009 Angka Kematian Ibu sebesar 226 per 100.000 kelahiran hidup. Angka Kematian Ibu tersebut sudah jauh menurun, namun masih jauh dari target Milenium Development Goals (MDGs) 2015 yaitu sebesar 102 per 100.000 kelahiran hidup, sehingga masih memerlukan kerja keras dari semua komponen untuk mencapai target tersebut. ${ }^{2}$

Di Provinsi Jawa Tengah AKI menurut data Dinas Kesehatan Provinsi Jawa Tengah pada tahun 2010 sebesar 104 per 100.000 KH, pada tahun 2011 AKI sebesar 116 per $100.000 \mathrm{KH}$, pada tahun 2012 AKI sebesar 100 per $100.000 \mathrm{KH}$, pada tahun 2013 sebesar 118 per $100.000 \mathrm{KH}$ dan pada tahun 2014 sebesar 99 per 100.000 KH.Data Angka Kematian Ibu di Kabupaten Sukoharjo dua tahun terakhir menunjukkan angka yang cenderung turun, yaitu dilihat, tahun 2011 sebesar 152,32 per $100.000 \mathrm{KH}$,pada tahun 2012 mengalami penurunan menjadi 92,54 per $100.000 \mathrm{KH}$, pada tahun 2013 menurun 95,9 per $100.000 \mathrm{KH}$ dan pada tahun 2014 
menurun lagi menjadi 98,7 per 100.000 $\mathrm{KH}^{3}$

Resiko tinggi dapat diantisipasi pada saat Antenatal Care (ANC). Antenal care (ANC) merupakan pelayanan kesehatan bagi ibu hamil dan janinnya oleh tenaga profesional meliputi pemeriksaan kehamilan sesuai dengan standar pelayanan yaitu minimal 4 kali pemeriksaan selama kehamilan. Cakupan Pelayanan ANC dapat dipantau melalui pelayanan kesehatan ibu hamil sesuai standar paling sedikit empat kali atau sering disebut dengan Cakupan K4. Cakupan K4 adalah kontak ibu hamil dengan tenaga kesehatan untuk mendapatkan pelayanan antenatal sesuai standar yang ditetapkan. Target Standar Pelayanan Minimal (SPM) untuk Cakupan K4 yaitu sebesar 95\%.4

Penilaian keberhasilan cakupan pelayanan kesehatan ibu dan bayi dapat dilihat dari keberhasilan kinerja tim KIA dan proses yang dilakukan tim KIA dalam mencapai tujuan. Salah satu indikator kesehatan ibu dan bayi dapat dilihat dari pencapaian cakupan kunjungan ibu hamil K4. Kegunaan cakupan kunjungan ibu hamil K4 adalah untuk mengukur mutu pelayanan ibu hamil, mengukur tingkat keberhasilan perlindungan ibu hamil melalui pelayanan standar dan paripurna, mengukur kinerja petugas kesehatan khususnya petugas KIA dalam penyelenggaran pelayanan ibu hamil.5

Pencapaian target K4 akan terlaksana jika dilakukan dengan adanya pelayanan tenaga kesehatan, maka pemerintah melalui tenaga kesehatan di Puskesmas mencanangkan program K4 dalam memberikan pelayanan kesehatan bagi ibu, neonatal, bayi dan anak balita.6 Hal ini sesuai dengan upaya yang dilakukan Depkes RI dalam mempercepat penurunan AKI adalah mendekatkan pelayanan kebidanan kepada setiap ibu yang membutuhkannya. Untuk mendukung upaya kesehatan dan pencapaian sasaran pembangunan maka diperlukan tenaga kesehatan dalam jumlah, jenis dan kualitas yang tepat dan dapat diandalkan khususnya dalam akselerasi penurunan Angka Kematian Ibu (AKI) dan Angka Kematian Bayi (AKB). ${ }^{7}$
Ibu yang tidak melakukan kunjungan ANC atau < 4 kali selama kehamilan dan memiliki bayi dengan berat lahir > 2500 gram mempunyai peluang lebih tinggi 2,6 kali untuk mengalami kematian neonatal dibandingkan dengan ibu yang melakukan kunjungan ANC $>4$ kali8 sedangkan penelitian lain menunjukkan bahwa ibu yang melahirkan pada umur < 20 tahunatau > 35 tahun dengan K4 yang tidak terpenuhi berisiko 4,3 kali untuk melahirkan anak yang akan meninggal pada masa neonatal. Ibu yang mengalami komplikasi persalinan, dengan $\mathrm{K} 4$ tidak terpenuhi berisiko 2,8 kali untuk mengalami kematian neonatal dini.5

Berdasarkan hasil wawancara dengan bidan di BPM Dyah Surti Gonilan Sukoharjo dengan wawancara kepada 10 orang informan awal diketahui bahwa sebanyak 6 orang menyatakan tidak rutin melakukan pemeriksaan kehamilan karena kesibukannya bekerja dan juga karena tidak ada yang mengantar serta sebanyak 4 orang sudah melakukan pemeriksaan kehamilan secara rutin. Berdasarkan latar belakang masalah tersebut menarik minat peneliti untuk melakukan penelitian dengan judul "Hubungan Kualitas Pelayanan dengan Kepatuhan Pemeriksaan Kehamilan (K4) pada Ibu Hamil Trimester III di BPM Dyah Surti Gonilan Sukoharjo Tahun 2017".

Tujuan penelitian ini adalah Mengetahui hubungan kualitas pelayanan dengan kepatuhan pemeriksaan kehamilan (K4) pada ibu hamil Trimester III di BPM Dyah Surti Gonilan Sukoharjo tahun 2017.

\section{Metode Penelitian}

Jenis penelitian ini menggunakan deskriptif kuantitatif dengan rancangan cross sectional. Teknik pengumpulan data menggunakan kuesioner untuk mengetahui kualitas pelayanan yang diukur dengan menggunakan skala Likert mulai dari Sangat Tidak Setuju (STS) diberi skor 1 sampai dengan Sangat Setuju (SS) diberi skor 4 sedangkan checklist untuk mengukur kepatuhan pada pemeriksaan kehamilan yaitu kunjungan baik bila $\geq 4$ dan kunjungan kurang apabila frekuensi pemeriksaan kehamilan 4. Dalam penelitian ini kuesioner juga dilakukan Uji validitas pada 30 orang dengan hasil uji 
validitas diperoleh nilai $\mathrm{r}$ hitung $(0,455 \mathrm{~s} / \mathrm{d}$ $0,841)>0,361$ sedangkan hasil uji reliabilitas diperoleh nilai cronbach alpha $0,904>0,60$ sehingga dinyatakan reliabel. Teknik analisis data menggunakan chi square $(\mathrm{p} \leq 0,05)$.

\section{Gambar 2.1 Kerangka Pemikiran}

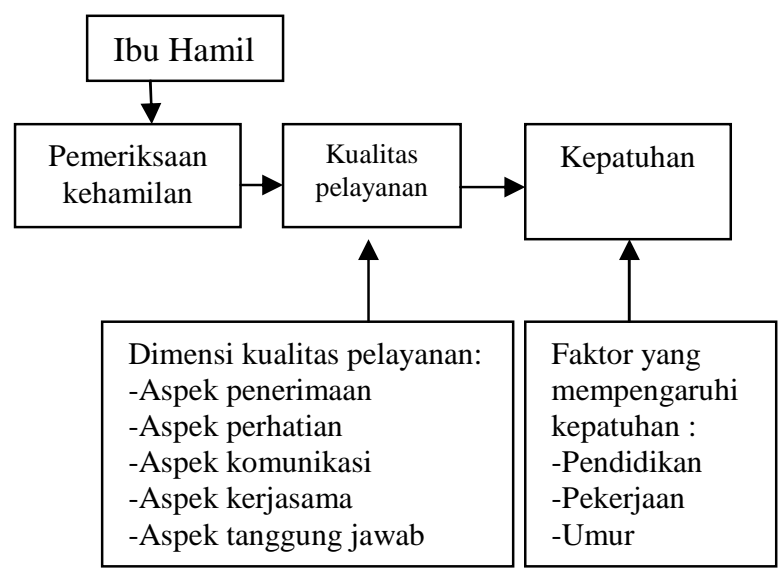

\section{Hasil dan Pembahasan}

Tabel 3.1. Distribusi Frekuensi Karakteristik Ibu hamil

\begin{tabular}{|l|l|l|}
\hline Karakteristik & f & $\%$ \\
\hline Umur & 4 & 10.8 \\
\hline$<20$ tahun & 22 & 59.5 \\
\hline $20-35$ tahun & 11 & 29.7 \\
\hline$>35$ tahun & 37 & 100.0 \\
\hline Total & 10 & 27.0 \\
\hline Pendidikan & 27 & 73.0 \\
\hline $\begin{array}{l}\text { Pendidikan } \\
\text { Rendah } \\
\text { +SMP) }\end{array}$ & 37 & 100.0 \\
\hline $\begin{array}{l}\text { Pendidikan } \\
\text { Tinggi (SMA + } \\
\text { Sarjana) }\end{array}$ & 13 & 35.1 \\
\hline Jumah & 24 & 64.9 \\
\hline Status Pekerjaan & 37 & 100.0 \\
\hline $\begin{array}{l}\text { Tidak Bekerja } \\
\text { (IRT) }\end{array}$ & 13 \\
\hline Bekerja & \\
\hline Total &
\end{tabular}

Hasil penelitian menunjukkan bahwa mayoritas umur responden adalah 20-35 tahun sebanyak 22 orang $(59,6 \%)$ dengan tingkat pendidikan tinggi sebanyak 27 responen $(73,0 \%)$ dan mayoritas responden bekerja yaitu sebanyak 24 orang $(64,9 \%)$.
Tabel 3.2. Distribusi Frekuensi Kualitas Pelayanan ANC

\begin{tabular}{|l|l|l|}
\hline Pelayanan & Frekuensi & $\%$ \\
\hline Kurang Baik & 15 & 40.5 \\
\hline Baik & 22 & 59.5 \\
\hline Jumlah & 37 & 100 \\
\hline
\end{tabular}

Hasil penelitian menunjukkan bahwa mayoritas responden yaitu sebanyak 22 responden $(59,5 \%)$ menyatakan bahwa kualitas pelayanan ANC di BPM Dyah Surti Gonilan Sukoharjo dalam kategori baik.

Tabel 3.3 Distribusi Frekuensi Kepatuhan pemeriksaan Kehamilan

\begin{tabular}{|l|l|l|}
\hline $\begin{array}{l}\text { Pemeriksaan } \\
\text { Kehamilan }\end{array}$ & Frekuensi & $\%$ \\
\hline Tidak Patuh & 14 & 37.8 \\
\hline Patuh & 23 & 62.2 \\
\hline Jumlah & 37 & 100 \\
\hline
\end{tabular}

Hasil penelitian menunjukkan bahwa mayoritas responden yaitu sebanyak 23 responden $(62,2 \%)$ menyatakan bahwa kepatuhan pemeriksaan kehamilan di BPM Dyah Surti Gonilan Sukoharjo dalam kategori patuh.

Hubungan kualitas pelayanan ANC dengan kepatuhan pemeriksaan kehamilan menggunakan chi square dengan hasil sebagai berikut:

Tabel 3.4.Hubungan kualitas pelayanan ANC dengan kepatuhan pemeriksaan kehamilan

\begin{tabular}{|c|c|c|c|c|c|}
\hline \multirow{2}{*}{$\begin{array}{c}\text { Kualitas } \\
\text { Pelayanan } \\
\text { ANC }\end{array}$} & \multicolumn{2}{|c|}{$\begin{array}{c}\text { Pemeriksaan } \\
\text { Kehamilan }\end{array}$} & \multirow[b]{2}{*}{ Total } & \multirow[b]{2}{*}{$X^{2}$} & \multirow[b]{2}{*}{$\begin{array}{c}p \\
\text { value }\end{array}$} \\
\hline & $\begin{array}{l}\text { Tidak } \\
\text { patuh }\end{array}$ & Patuh & & & \\
\hline \multirow{2}{*}{$\begin{array}{c}\text { Kurang } \\
\text { Baik }\end{array}$} & 9 & 6 & 15 & \multirow{6}{*}{5,268} & \multirow{6}{*}{0,022} \\
\hline & $24,3 \%$ & $16,2 \%$ & 40,5 & & \\
\hline \multirow{2}{*}{ Baik } & 5 & 17 & 22 & & \\
\hline & $13,5 \%$ & $46,0 \%$ & 59,5 & & \\
\hline \multirow[b]{2}{*}{ Total } & 14 & 23 & 37 & & \\
\hline & $37,8 \%$ & $62,2 \%$ & $\begin{array}{c}100.0 \\
\%\end{array}$ & & \\
\hline
\end{tabular}

Berdasarkan hasil crosstabulasi tersebut dari 37 responden diketahui bahwa sebanyak 15 orang menyatakan bahwa kualitas pelayanan ANC kurang baik dimana sebanyak 9 orang $(24,3 \%)$ menyatakan tidak patuh dalam pemeriksaan kehamilan dan sebanyak 6 orang $(16,2 \%)$ menyatakan patuh dalam 
pemeriksaan kehamilan. Sebanyak 22 orang menyatakan bahwa kualitas pelayanan ANC baik dimana sebanyak 5 orang $(13,5 \%)$ menyatakan tidak patuh dalam pemeriksaan kehamilan dan sebanyak 17 orang $(46,0 \%)$ menyatakan patuh dalam pemeriksaan kehamilan.

Analisis data dengan menggunakan uji chi square didapatkan hasil nilai $\mathrm{X} 2=$ 5,268 dengan nilai $\mathrm{p}$ value $0,022<0,05$, maka Ho ditolak sehingga dapat dinyatakan ada hubungan yang bermakna antara kualitas pelayanan ANC dengan kepatuhan pemeriksaan kehamilan Ibu hamil Trimester III yang melakukan pemeriksaan kehamilan di BPM Dyah Surti Gonilan Sukoharjo.

Hasil penelitian menunjukkan bahwa mayoritas umur responden adalah 20-35 tahun sebanyak 22 orang $(59,6 \%)$. Umur merupakan ciri dari kedewasaan fisik dan kematangan kepribadian yang erat hubungannya dengan pengambilan keputusan, mulai umur 21 tahun secara hukum dikatakan mulai masa dewasa dan pada 30 tahun telah mampu menyelesaikan masalah dengan cukup baik, menjadi stabil dan tenang secara emosional. ${ }^{9}$ Semakin cukup umur, tingkat kematangan dan kekuatan seseorang akan lebih matang dalam berpikir dan bekerja. Sehingga ketika ibu mendapatkan masalah proses pemecahan masalahnya dapat lebih matang ${ }^{10}$. Dengan bertambahnya umur seseorang maka kematangan dalam berpikir semakin baik sehingga akan termotivasi dalam memeriksakan kehamilan, juga mengetahui akan pentingnya Antenatal Care dan semakin muda umurnya semakin tidak mengerti tentang pentingnya pemeriksaan kehamilan. Kepatuhan ibu dipengaruhi oleh usia 20-35 tahun karena pada usia 2035 tahun merupakan usia reproduksi sehat sehingga wanita pada usia ini menyadari akan kebutuhan kesehatan terutama pada saat hamil. ${ }^{11}$

Hasil penelitian menunjukkan bahwa mayoritas tingkat pendidikan responden adalah pendidikan tinggi yaitu sebanyak 27 responen $(73,0 \%)$ Pendidikan yang didapat seseorang dapat membuat individu tersebut mengalami perubahan perilku, semakin tinggi pendidikan seseorang maka dalam memilih tempat-tempat pelayanan kesehatan semakin diperhitungkan. Semakin tinggi tingkat pendidikan seseorang maka akan lebih mudah untuk menerima dan mengerti pesan-pesan kesehatan, begitupun sebaliknya semakin rendah pendidikan seseorang maka semakin sulit pula dalam menerima dan mengerti pesan-pesan kesehatan yang disampaikan. ${ }^{12}$ Hal ini didukung penelitian terdahulu bahwa pendidikan memiliki hubungan terhadap kelengkapan pemeriksaan kehamilan. ${ }^{13}$

Hasil penelitian menunjukkan bahwa mayoritas responden adalah bekerja yaitu sebanyak 24 orang $(64,9 \%)$. Status pekerjaan juga membuat ibu tidak patuh dalam pemeriksaan kehamilan hal ini karena dengan bekerja atau menjadi sebagai ibu rumah tangga bisa membuat ibu hamil mengalami lelah dan berpengaruh terhadap kandungan dan minimnya waktu untuk memeriksakan kehamilannya kepada petugas kesehatan. Pekerjaan sangat menentukan terhadap seseorang untuk berbuat suatu kegiatan. Pekerjaan yang dimaksud adalah pekerjaan ibu, dengan banyak kesibukan maka ibu kadang-kadang lupa untuk melakukan pemeriksaan kehamilan tepat waktu. ${ }^{14}$ Tetapi, pekerjaan bukanlah penghambat dalam bertindak bila ada kemauan ataupun ibu melakukan tindakan dalam hal ini memeriksakan kehamilannya. Ibu hamil yang bekerja bukan saja mempunyai sumber penghasilan untuk melakukan pemeriksaan kehamilan, tetapi juga dalam pekerjaannya dapat berinteraksi dengan orang lain yang lebih memahami tentang pentingnya melakukan pemeriksaan kehamilan, sehinggan ibu yang bekerja tersebut lebih mengetahui dan mau memeriksakan kehamilannya. ${ }^{15}$

Berdasarkan hasil analisis yang telah dilakukan diketahui bahwa mayoritas responden yaitu sebanyak 22 orang $(59,5 \%)$ menyatakan bahwa tingkat kualtias pelayanan ANC dalam kategori baik. Pelayanan bidan dalam kategori baik ini berdasarkan hasil kuesioner diketahui bahwa bidan segera melakukan pertolongan ketika ibu hamil mengalami keluhan yang serius atau terjadi kegawatan pada kehamilan, bidan tekun dalam pelaksanaan pemeriksaan ANC, bidan dalam pemeriksaan ANC dapat 
melaksanakan tugasnya dengan baik, bidan mampu berkomunikasi dengan baik, bidan fokus dalam pemeriksaan ANC, bidan sudah melakukan tindakan medis dengan tepat, bidan mampu memberikan penjelasan pada ibu hamil dengan baik.

Antenatal Care merupakan pengawasan sebelum persalinan terutama ditujukan pada pertumbuhan dan perkembangan janin dalam rahim.4 Pemeriksaan kehamilan atau antenatal care yang baik akan memberi manfaat bagi ibu hamil antara lain menurunkan angka kematian maternal, yaitu dengan mengidentifikasi faktor risiko yang berhubungan dengan usia, paritas, riwayat obstetrik buruk dan perdarahan selama kehamilan, sehingga dapat ditentukan pertolongan persalinan yang aman. Selain itu ibu hamil dapat mendapatkan konseling tentang kehamilannya, kesehatan reproduksi dan alat kontrasepsi.16 Berdasarkan hal tersebut maka dapat disimpulkan oleh peneliti bahwa pelayanan bidan dalam kualitas pelayanan ANC dalam kategori baik, karena bidan dapat berkomunikasi dengan baik, tanggap terhadap keluhan yang diberikan serta melaksanakan tugasnya dengan baik.

Hasil penelitian menunjukkan bahwa mayoritas responden yaitu sebanyak 23 responden $(62,2 \%)$ menyatakan patuh dalam pemeriksaan kehamilan di BPM Dyah Surti Gonilan Sukoharjo. Hal ini berarti bahwa responden patuh terhadap pemeriksaan kehamilan, karena mereka beranggapan bahwa pemeriksaan kehamilan merupakan hal yang harus dilakukan guna menjaga kesehatan ibu dan janin. Hal ini sesuai dengan tujuan dilakukannya ANC adalah untuk mempromosikan dan menjaga kesehatan fisik, mental ibu dan bayi, serta mendeteksi dan menatalaksanakan komplikasi medis, bedah, maupun obstetric, mengembangkan persiapan persalinan, membantu menyiapkan ibu untuk menyusui, merawat anak secara fisik, psikologi dansosial.17 Kepatuhan Ibu hamil trimester III dalam pemeriksaan kehamilan merupakan kebutuhan ibu untuk memastikan kesehatan ibu dan janin. 4

Hasil penelitian menunjukkan bahwa hubungan yang bermakna antara kualitas pelayanan ANC dengan kepatuhan pemeriksaan kehamilan Ibu hamil Trimester III yang melakukan pemeriksaan kehamilan di BPM Dyah Surti Gonilan Sukoharjo dengan nilai X2 $=5,268$ dan $\mathrm{p}$ value $0,022<0,05$.

Pelayanan antenatal merupakan pelayanan kesehatan oleh tenaga profesional yang diberikan kepada ibu selama masa kehamilan yang dilaksanakan sesuai dengan standar pelayananan tenatal. Pemeriksaan ini bertujuan memeriksa keadaan ibu dan janin secara berkala diikuti dengan upaya koreksi terhadap penyimpangan yang ditemukan, dengan frekuensi kunjungan 4 kali selama kehamilannya, yaitu 1 kali pada trimester pertama, 1 kali pada trimester kedua dan 2 kali padatrimester ketiga. Pemeriksaan medis dalam pelayanan antenatal meliputi anamnesis, pemeriksaan fisik, diagnosis, pemeriksaan obstetrik dan pemeriksaan diagnosis penunjang. ${ }^{17}$

Semua ibu hamil yang K4 dan yang tidak K4 membutuhkan pelayanan ANC yang lebih memiliki kualitas. Adanya komunikasi interpersonal antara pemberi pelayanan ANC dengan pasien diperlukan karena ibu hamil membutuhkan informasi yang komprehensif agar dapat mengetahui perkembangan kehamilannya. Ibu hamil menginginkan bahwa bidan dalam memberikan pelayanan sesuai dengan standar operasional procedur (SOP) untuk meningkatkan kepatuhan bidan supaya bidan tidak salah dalam memberikan pelayanan, bidan juga perlu melakukan pendekatan terapeutik pada ibu dan keluarga. Pendekatan komunikasi yang diberikan oleh bidan kepada ibu hamil bertujuan untuk membuat ibu dan keluarga lebih percaya kepada bidan dalam memberikan pelayanan antenatal care, selain itu bidan juga perlu menggunakan bahasa yang dimengerti adalah upaya untuk peningkatan bidan dalam kunjungan K4 tentang pemberian informasi yang jelas kepada ibu hamil supaya ibu hamil tidak salah mempersepsikan informasi yang diberikan oleh bidan. ${ }^{18}$

Semua ibu hamil baik yang K4 maupun tidak K4 di Puskesmas membutuhkan competency, assurance, responsiveness, communication, kenyamanan dan keamanan yang diberikan oleh bidan. Keinginan ibu hamil ini dikuatkan dengan 
harapan tentang adanya pelayanan antenatal care yang ditangani oleh bidan yang berkualitas baik dari sisi kompetensi maupun komunikasi interpersonal. Semakin puas ibu hamil terhadap competency, assurance, responsiveness, empathy, communication, caring, physical environment, kenyamanan dan keamanan maka kemungkinan untuk memanfaatkan pelayanan ANC di Puskesmas lebih tinggi. $^{18}$

Pemeriksaan kehamilan sangat dipengaruhi oleh faktor internal ibu hamil. Faktor internal yang mungkin muncul dari seorang ibu hamil terhadap kunjungan $\mathrm{K} 4$ ibu hamil antara lainseperti: usia, pendidikan, paritas, pengetahuan,sikap, dan dukungan keluarga. Antenatal caresedangkan faktor eksternal yang mempengaruhi antara lain adalah media dan pelayanan yang diberikan tenaga kesehatan. ${ }^{19}$ Kepatuhan ibu hamil dalam kunjungan ANC atau pemeriksaan kehamilan merupakan hasil dari pengaruh faktor internal dan faktor eksternal. faktor eksternal tersebut berupa stimulus untuk membentuk dan mengubah sikap yang dipengaruhi melalui perantara dalam hal ini adalah bidan. Kepatuhan atau ketaatan pemeriksaan kehamilan memberikan manfaat dengan ditemukannya berbagai kelainan yang menyertai kehamilan secara dini, sehingga dapat diperhitungkan dan dipersiapkan langkah-langkah dan pertolongan persalinannya. Diketahui bahwa janin dalam rahim dan ibunya merupakan satu kesatuan yang paling mempengaruhi pertumbuhan dan perkembangan janin. Kepatuhan pemeriksaan kehamilan dipengaruhi oleh pelayanan kebidanan ${ }^{4}$. Hasil ini menunjukkan bahwa hubungan antara pelayanan ANC dengan kepatuhan $\mathrm{ANC}^{20}$.

\section{Kesimpulan}

Mayoritas umur responden adalah 2035 tahun sebanyak 22 orang $(59,6 \%)$ dengan tingkat pendidikan tinggi sebanyak 27 responen $(73,0 \%)$ dan mayoritas responden bekerja yaitu sebanyak 24 orang $(64,9 \%)$.

Mayoritas responden yaitu sebanyak 22 orang $(59,5 \%)$ menyatakan bahwa kualtias pelayanan ANC di BPM Diyah Surti Gonilan Sukoharjo. dalam kategori baik.
Mayoritas responden yaitu sebanyak 23 responden $(62,2 \%)$ menyatakan patuh dalam pemeriksaan kehamilan di BPM Diyah Surti Gonilan Sukoharjo.

Ada hubungan yang bermakna antara kualitas pelayanan ANC dengan kepatuhan pemeriksaan kehamilan Ibu hamil Trimester III yang melakukan pemeriksaan kehamilan di BPM Dyah Surti Gonilan Sukoharjo dengan nilai $\mathrm{X}^{2}=5,268$ dan $p$ value $0,022<0,05$.

\section{Daftar Pustaka}

[1] Undang-Undang NO. 36 Tahun 2009 tentang Kesehatan

[2] Depkes RI. 2014. Capaian MDGs Bidang Kesehatan Jakarta : Depkes

[3] Dinas Kesehatan Kabupaten Sukoharjo Tahun 2014.

[4] Manuaba., I. B. G. 2012, Ilmu Kebidanan, Penyakit Kandungan dan KB untuk Pendidikan Bidan, Jakarta: EGC.

[5] Lolong, DB dan Pangaribuan, L. 2015. Hubungan Kunjungan K4 dengan Kematian Neonatal Dini di Indonesia (Analisis Lanjut Data Riskesdas 2013). Media Litbangkes, Vol. 25 No. 3, hal. $139-146$.

[6] Ervin O. 2012. Beberapa faktor yang berhubungan dengan kinerja bidan desa dalam pencapaian target $K 4 \mathrm{di}$ kabupaten Ngawi. Semarang: Universitas Dipenogoro.

[7] Ramadhani, RN. 2012. Sistem Informasi Kesehatan. Jakarta: Bumi Aksara.

[8] Latifah AN. 2012. Hubungan Frekuensi Kunjungan ANC Selama Kehamilan dengan Kejadian Kematian Neonatal. Analisis Data SDKI 2007. Tesis, Program Pascasarjana Program Studi Ilmu Kesehatan Masyarakat Kekhususan Biostatistika dan Kependudukan, Fakultas Kesehatan Masyarakat, Depok: Universitas Indonesia.

[9] Abu, A.D.K.H, Kusumawati, Y DAN Werdani, KE. 2015. Hubungan Karakteristik Bidan dengan Mutu Pelayanan Antenatal Care Berdasarkan Standar Operasional. Jurnal Kesehatan Masyarakat Andalas. Vol. 10, No. 1, Hal. 94-100. 
[10] Nursalam. 2015. Konsep dan Penerapan Metode Penelitian Ilmu Keperawatan Pedoman Skripsi, Tesis dan Instrument Penelitian Keperawatan. Jakarta : Salemba Medika.

[11] Rikhly F.M, Mawarni., A dan Farid A. 2012. Kepuasan Ibu Hamildan PersepsiKualitas Pelayanan Antenatal Care di Puskesmas TunjungKabupaten Sampang Madura. Media KesehatanMasyarakat, Vol.11 No.2,

[12] Notoatmodjo, S. 2014.Metodologi Penelitian Kesehatan. Jakarta : Rineka Cipta.

[13] Wulandari, EC dan Ariesta, R. 2014. Hubungan Pendidikan dan Umur Ibu Hamil denganKelengkapan Pemeriksaan Kehamilan (K4). Jurnal Obstretika Scientia Vol. 2 No. 2, hal. 160-177.

[14] Rohan \& Siyoto, H.S. 2013. Buku Ajar Kesehatan Reproduksi. Yogyakarta : Nuha Medika.

[15] Lumempouw, V.J.R., Kundre, RM., Bataha, Y. 2016. Hubungan Faktor Sosial Ekonomi Ibu Hamil Dengan Keteraturan Pemeriksaan Antental Care (ANC) di Puskesmas Ranotana
Weru Kecamatan Wanea Kota Manado. e-journal Keperawatan (e$K p$ ). Vol 4 No 2, hal 1-7.

[16] Wiknjosastro, Hanifa. 2010. Ilmu Kandungan. Jakarta: Yayasan Bina Pustaka. Sarwono Prawirohardjo.

[17] Kusmiati, dkk. 2015. PanduanLengkap Perawatan Kehamilan.Yogyakarta: Fitramaya

[18] Yanuaria, MR dan Wulandari, RD. 2013. Penyusunan Upaya Peningkatan Pelayanan Antenatal Care Berdasarkan Voice Of The Customer. Jurnal Administrasi Kesehatan Indonesia. Vol 1 No 1 Hal 66-74.

[19] Hidayatun , MS,. 2014. Analisis Faktor Ibu HamilTerhadap Kunjungan Antenatal Care di Puskesmas Siwalan Kerto KecamatanWonocolo Kota Surabaya. Jurnal Promkes. Vol 2 No. 1, hal 39-48.

[20] Wulandatika, D. 2017. Faktor-Faktor yang Berhubungan dengan Kepatuhan Ibu dalam Melakukan Kunjungan Antenatal Care Di Wilayah Kerja Puskesmas Gambut Kabupaten Banjar, Kalimantan Selatan. Jurnal Ilmu Keperawatan dan Kebidanan.Vol.8 No.2 (2017) 8-18 